\title{
Discovery of chrenic and apochrenic acids in the mineral waters of porta
}

\section{Berzelius}

To cite this article: M. Berzelius (1834) Discovery of chrenic and apochrenic acids in the mineral waters of porta, Philosophical Magazine Series 3, 5:27, 238-239, DOI: $10.1080 / 14786443408649451$

To link to this article: http://dx.doi.org/10.1080/14786443408649451

册 Published online: 01 Jun 2009.

Submit your article to this journal $₫$

Џ Article views: 2

Q View related articles $₫$ 
These observations give an increase of $1^{\circ}$ centigrade in descending through 18.32 netres,

Kupffer's observations in the mine of Bogoslowsk in the Ural, give an increase of $1^{\circ}$ centigrade in descending through 19.84 metres.-Poggendorff's Annalen, v. 32.

ON THE PHYSICAL AND THERAPEUTIC PROPERTIES OF CHROMATE OF PO'TASH. BY M. JACOBSON.

Neutral chromate of potash may be exposed to a very high temperature without being decomposed, unless charcoal be added to it, which renders it incandescent. Hemp, cotton, linen, or cloth, impregnated with this salt become very combustible, and burn with strong and lively incandescence, and with considerable disengagement of light and heat. The oxides of chromium and its different salts possess the same property. The author has employed this property of chromate of potash for the preparation of moxas. Those which he made use of were made with blotting-paper soaked in a solution made with one part of this salt and 16 parts of water: the author proposes to make matches by immersing cotton in this solution. An important property of this salt is its great solubility in water, and its power of preserving vegetable and animal matter from putrefaction; it also removes the disagreeable smell from putrid substances.

The bichromate is especially suited for preservation and disinfection, the solution containing about 1.250 of its weight of the salt. Animal substances, with the exception of the nervous parts, are not at all altered by this solution. With respect to the therapeutic properties of chromate of potash, M. Jacobson employs it externally as a resolvent, and when concentrated, as a caustic. Internally, taken in doses of 1 or 2 grains, it is emetic.-Journal de Chimie Médicale, Février 1834.

DISCOVERY OF CHRENIC AND APOCHRENIC ACIDS IN THE MINERAL WATERS OF PORTa. BY M. BERzELIUS.

The waters of Porta have acquired great celebrity on account of their medicinal properties. The water is abundant, and bubbles of gas, which consist of 6 volumes of azote and 1 volume of carhonic acid, constantly rise from the bott om of the spring : the temperature of the water is invariably about $4.5^{\circ} \mathrm{Fahr}$. The colour of the water is yellowish, and caused by an organized substance which it is difficult to isolate; it is composed of oxygen, hydrogen, azote and carbon. It possesses acid properties, and when coricentrated has a sour taste: it is a mixture of twoacids, one of which, occurring in the greatest quantity, Berzelius calls chrenic acid, and the other apochrenic acid, because it is formed from the first by the influence of oxygen gas, \&c. These acids are weak; they nevertheless decompose the acetates if the mixture is evaporated. Chrenic acid does not crystallize : the solution concentrated to the consistence of a syrup is almost colourless. When dried in vacuo it splits in all directions, and has a false appearance of being crystallized; its taste is then distinctly acid and astringent. The watery solution has only an 
astringent taste; it is soluble in absolute alcohol, and but slightly so in alcohol of density 0.85 . The chrenates of the alkaline earths are but slightly soluble in water, and they form insoluble subsalts. The greater part of other chrenates are insoluble except the protochrenate of iron, which is very soluble.

Apochrenic acid is but slightly soluble in water, to which it gives a brownish colour. The apochrenates resemble the chrenates strongly, but they are brown or black, insoluble in alcohol, and combine with hydrate of alumina by digestion, forming a colourless solution. By this method they are easily separated from the chrenates.

These two acids are found in several chalybeate waters in Sweden, even when the waters are colourless. They may be separated from the ochre which these waters deposit by boiling it with hydrate of potash. The alkali being afterwards saturated with acetic acid, the apochrenic acid is to be precipitated by acetate of lead as long as a brown precipitate is formed, or a greenish one, which becomes brown. The liquor afterwards neutralized by an alkaline carbonate precipitates chrenate of copper in greenish white flocks, the quan. tity of which is increased by adding more acetate of copper. The copper is afterwards separated from the acid by means of sulphuretted hydrogen. Even ochry iron ore contains these acids.

The waters of Porta contain these two acids in the states of the chrenates of soda and ammonia. In 100,000 parts of the water there were found,

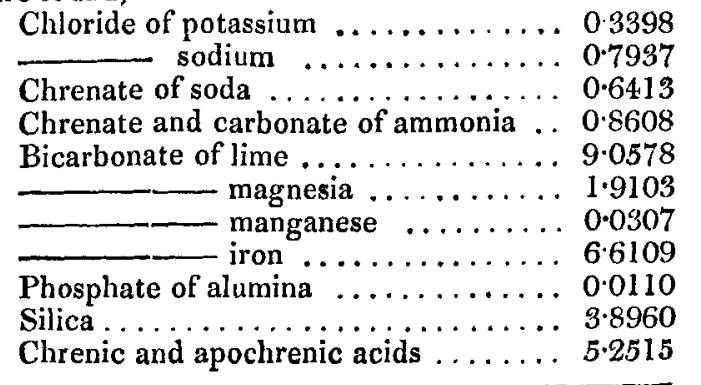

$29 \cdot 4038$

Berzelius considers the azote disengaged from the water, and the ammonia which saturates the chrenic acid, as the product of the spontaneous decomposition of the two organic acids; and he attributes the acids to the putrefaction of vegetable substances on the surface of the earth, in the extensive marshy forests which surround the spring.-Journal de Chimie Médicale, Arril 1834.

\section{SCIENTIFIC BOOKS.}

\section{In the Press.}

A Guide to Geology; explaining the Elementary Facts and Inferences of that Science, with condensed Descriptions of the principal Stratified and Unstratified Rocks, Tables, Plates, \&c. By Professor Phillips. 